\title{
The American Model of the Multinational Firm and the "New" Multinationals From Emerging Economies
}

\author{
by Mauro F. Guillén and Esteban García-Canal
}

\begin{abstract}
Executive Overview
The traditional American model of multinational enterprise (MNE), characterized by foreign direct investment (FDI) aimed at exploiting firm-specific capabilities developed at home and a gradual countryby-country approach of internationalization, dominated the global economy during much of the postWorld War II period. In the last two decades, however, new MNEs from emerging, upper-middle-income, or oil-rich countries have followed completely different patterns of international expansion. In this paper we analyze the processes through which these firms became MNEs and to what extent we need a new theory to explain their international growth.
\end{abstract}

T he modern multinational enterprise (MNE) as we know it today has its origins in the second industrial revolution of the late 19th century. British, North American, and continental European firms expanded around the world on the basis of intangible assets such as technology, brands, and managerial expertise. The climax of their worldwide expansion was reached during the 1950s and '60s, as trade and investment barriers gradually fell around the world (Chandler, 1990; Kindleberger, 1969; Vernon, 1979; Wilkins, 1974).

While significant variations in the strategy and structure of North American and European multinationals were documented at the time (e.g., Stopford \& Wells, 1972) and the rise of Japanese multinationals during the 1970s and '80s added yet more diversity to the global population of multinational corporations, firms expanding from relatively rich and technologically advanced countries tended to share a core set of features. Chief among them were their technological, marketing, and managerial strengths, which enabled

Financial support provided by the Fundación Rafael del Pino is gratefully acknowledged. them to overcome the so-called liability of foreignness in a variety of markets, investing for the most part in wholly or majority-owned subsidiaries, transferring technology, products, and knowledge from headquarters to far-flung operations around the globe, and relying on elaborate bureaucratic and financial controls.

This relatively straightforward state of affairs is changing rapidly. Since the 1990s, the global competitive landscape is becoming increasingly populated by MNEs originating in countries that are not among the most advanced in the world. These "new" MNEs come from (a) upper-middleincome economies such as Spain, Portugal, South Korea, and Taiwan; (b) emerging economies such as Brazil, Chile, Mexico, China, India, and Turkey; (c) developing countries such as Egypt, Indonesia, and Thailand; and (d) oil-rich countries such as the United Arab Emirates, Nigeria, and Venezuela. The new MNEs operate internationally using multiple entry modes, ranging from alliances and joint ventures to wholly owned subsidiaries. Some of them are small and product focused, while others are large and diversified

\footnotetext{
* Mauro F. Guillén (guillen@wharton.upenn.edu) is Dr. Felix Zandman Professor in International Management; Professor of Management and Sociology; and Director, Joseph H. Lauder Institute for Management \& International Studies, The Wharton School. Esteban García-Canal (egarcia@uniovi.es) is a Professor of Management, Universidad de Oviedo.
} 
across many industries. The literature has referred to them in a variety of ways, including "thirdworld multinationals" (Wells, 1983), "latecomer firms" (Mathews, 2002), "unconventional multinationals" (Li, 2003), "challengers” (BCG, 2008), and "emerging multinationals" (Accenture, 2008; Economist, 2008; Goldstein, 2007). While they may not possess the most sophisticated technological or marketing skills in their respective industries, they have expanded around the world in innovative ways. They have become key actors in foreign direct investment and cross-border acquisitions (UNCTAD, 2006).

The new multinationals from the $\mathrm{BRIC}^{1}$ countries have made great inroads into the global economy. Among Brazilian firms, Companhia Vale do Rio Doce and Metalúrgica Gerdau are among the largest firms in mining and steel, Embraer holds with Bombardier of Canada a duopoly in the global regional jet market, and Natura Cosméticos has a presence in both Latin America and Europe. Lukoil, Gazprom, and Severstal are among the Russian multinationals, while India boasts an army of firms not only in IT and outsourcing services, in which companies such as Infosys, TCS, and Wipro are among the largest in the world, but also in steel, automobiles, and pharmaceuticals. Chinese firms have irrupted with force in global markets not only as exporters but also as foreign investors, and in every industry from mining and oil to chemicals and steel. In electrical appliances and electronics, China boasts three increasingly well-known firms: Haier, Lenovo, and Huawei.

Multinationals from the so-called Asian tiger economies-those that industrialized during the 1960s — are among the earliest new multinationals from countries other than the most advanced. Taiwan, a country that excels both at technological and process innovation, has proved to be the most fertile ground for outward foreign investors, including such powerhouses as Formosa Plastics, Taiwan Semiconductor, and Acer. Following a path to development much more oriented toward large-scale industry, South Korea is home to some of the best known names in the electronics and

\footnotetext{
${ }^{1}$ Brazil, Russia, India, and China.
}

appliances industries (Samsung and LG) and automobiles (Hyundai and Kia). The city-state of Singapore has bred multinationals in food and beverages (Fraser and Neave, Want Want), electronics (Olam), telecommunications (Singtel), real estate (Capitaland), transportation (Neptune Orient Lines), and hotels (City Developments). For its part, Hong Kong is home to a large number of multinationals in a similar set of industries, led by Hutchinson Whampoa, the world's largest port operator.

In addition to South Korea and Taiwan, Spain has produced the largest number of truly global multinationals among the countries that back in the 1960s were still attempting to develop a solid industrial base. In food processing, Spanish companies have made important acquisitions in Europe, Asia, and the Americas, turning themselves into the world's largest producers of rice and olive oil and the second-largest of pasta. In the textiles and clothing sector, Spain has also produced companies of international stature, such as global denim leader Tavex (now merged with Brazil's Santista); Inditex, which owns the world's second-most valuable brand (Zara); and Pronovias, the largest bridal wear designer and manufacturer. Spanish firms in telecommunications (Telefónica), electricity (Endesa, Iberdrola), and banking (Santander, BBVA) are among the largest MNEs in their respective industries.

In Spanish-speaking Latin America some firms from Mexico and Argentina stand out as formidable global competitors. In food processing, Bimbo and Gruma are among the largest in their respective market niches, namely, packaged bread and tortillas. In cement, Cemex is the second- or third-largest, depending on the specific product. Grupo Modelo is the third-largest brewery in the world. These companies have made acquisitions or greenfield investments in North America, Asia, and Europe. Argentina's Tenaris is the global leader in seamless steel tubes, and Industrias Metalúrgicas Pescarmona is a major firm in the crane business.

The Middle East is also becoming the home base of major multinational corporations, including DP World of Dubai (the world's second-largest port operator), Orascom (the Egyptian construc- 
tion and telecommunications group with major operations throughout Africa and the Middle East), Mobile Telecommunications Company (the Kuwaiti giant), and Enka Insaat ve Saayi (the Turkish infrastructure group).

The proliferation of the new MNEs has taken observers, policymakers, and scholars by surprise. Many of these firms were marginal competitors just a decade ago; today they are challenging some of the world's most accomplished and established multinationals in a wide variety of industries and markets. The unexpected rise to prominence of firms such as Cemex of Mexico, Embraer of Brazil, Haier of China, Tata Consultancy Services of India, and Banco Santander of Spain raises three fundamental questions: First, do these firms share some common features that distinguish them from the traditional American model of the MNE? Second, what advantages have made it possible for them to operate and compete not only in host countries at the same or lower level of economic development but also in the richest economies? Third, why have they been able to expand abroad at dizzying speed, in defiance of the conventional wisdom about the virtues of a staged, incremental approach to international expansion? Before being in a position to answer these questions, one must begin by outlining the established theory of the MNE.

\section{The Theory of the Multinational Firm}

A lthough MNEs have existed for a very long time, scholars first attempted to understand the nature and drivers of their cross-border activities during the 1950s. The credit for providing the first comprehensive analysis of the MNE and of foreign direct investment goes to economist Stephen Hymer, who in his doctoral dissertation observed that the "control of the foreign enterprise is desired in order to remove competition between that foreign enterprise and enterprises in other countries ... or the control is desired in order to appropriate fully the returns on certain skills and abilities" (Hymer, 1960, p. 25). His key insight was that the multinational firm possesses certain kinds of proprietary advantages that set it apart from purely domestic firms, thus helping it overcome the "liability of foreignness."
Multinational firms exist because certain economic conditions and proprietary advantages make it advisable and possible for them to profitably undertake production of a good or service in a foreign location. It is important to distinguish between vertical and horizontal foreign expansion in order to fully understand the basic economic principles that underlie the activities of MNEs in general and the novelty of the "new" MNEs in particular.

\section{Vertical Expansion}

Vertical expansion occurs when the firm locates assets or employees in a foreign country with the purpose of securing the production of a raw material, component, or input (backward vertical expansion) or the distribution and sale of a good or service (forward vertical expansion). The necessary condition for a firm to engage in vertical expansion is the presence of a comparative advantage in the foreign location. The advantage typically has to do with the prices or productivities of production factors such as capital, labor, or land. For instance, a clothing firm may consider production in a foreign location due to lower labor costs.

It is important, though, to realize that the mere existence of a comparative advantage in a foreign location does not mean that the firm ought to vertically expand. The necessary condition of lower factor costs or higher factor productivity, or both, is not sufficient. After all, the firm could benefit from the comparative advantage in the foreign location simply by asking a local producer to become its supplier. The sufficient condition justifying a vertical foreign investment refers to the possible reasons encouraging the firm to undertake foreign production by itself rather than relying on others to do the job. The two main reasons are uncertainty about the supply and asset specificity. If uncertainty is high, the firm would prefer to integrate backward into the foreign location to make sure that the supply chain functions smoothly, and that delivery timetables are met. Asset specificity is high when the firm and the foreign supplier need to develop joint assets in order for the supply operation to take place. In that situation the firm would prefer to expand backward in order to avoid the "hold-up" problem, 
that is, opportunistic behavior on the part of the foreign supplier trying to extract rents from the firm. These necessary and sufficient conditions also apply in the case of forward vertical expansion into a foreign location. Uncertainty and asset specificity with, say, a foreign distributor would compel the firm to take things into its own hands and invest in the foreign location in order to make sure that the goods or services reach the buyer in the appropriate way and at a reasonable cost.

\section{Horizontal Expansion}

Horizontal expansion occurs when the firm sets up a plant or service delivery facility in a foreign location with the goal of selling in that market, and without abandoning production of the good or service in the home country. The decision to engage in horizontal expansion is driven by forces different than those for vertical expansion. Production of a good or service in a foreign market is desirable in the presence of protectionist barriers, high transportation costs, unfavorable currency exchange rate shifts, or requirements for local adaptation to the peculiarities of local demand that make exporting from the home country unfeasible or unprofitable. As in the case of vertical expansion, these obstacles are a necessary condition for horizontal expansion, but not a sufficient one. The firm should ponder the relative merits of licensing a local producer in the foreign market or establishing an alliance against those of committing to a foreign investment. The sufficient condition for setting up a proprietary plant or service facility has to do with the possession of intangible assets-brands, technology, know-how, and other firm-specific skills-that make licensing a risky option because the licensee might appropriate, damage, or otherwise misuse the firm's assets. ${ }^{2}$

Scholars in the field of international management have also acknowledged that firms in possession of the requisite competitive advantages do not become MNEs overnight, but in a gradual way, following different stages. According to the framework originally proposed by researchers at

\footnotetext{
${ }^{2}$ For a summary of the basic economic model of the multinational firm, see Caves (1996). Stephen Hymer (1960) was the first to observe that firms expand horizontally to protect (and monopolize) their intangible assets.
}

the University of Uppsala in Sweden (Johanson \& Vahlne, 1977; Johanson \& Wiedersheim-Paul, 1975), firms expand abroad on a country-by-country basis, starting with those more similar in terms of sociocultural distance. They also argued that in each foreign country firms typically followed a sequence of steps: on-and-off exports, exporting through local agents, sales subsidiary, and production and marketing subsidiary. A similar set of explanations and predictions were proposed by Vernon $(1966,1979)$ in his application of the product life cycle to the location of production. According to these perspectives, the firm commits resources to foreign markets as it accumulates knowledge and experience, managing the risks of expansion and coping with the liability of foreignness. An important corollary is that the firm expands abroad only as fast as its experience and knowledge allow.

\section{Enter the "New" Multinationals}

$\mathrm{T}$ The early students of the phenomenon of MNEs from developing, newly industrialized, emerging, or upper-middle-income countries focused their attention on both the vertical and the horizontal investments undertaken by these firms, but they were especially struck by the latter. Vertical investments, after all, are easily understood in terms of the desire to reduce uncertainty and minimize opportunism when assets are dedicated or specific to the supply or the downstream activity, whether the MNE comes from a developed country or not (Caves, 1996, pp. 238-241; Lall, 1983; Lecraw, 1977; Wells, 1983). The horizontal investments of the new MNEs, however, are harder to explain because they are supposed to be driven by the possession of intangible assets, and firms from developing countries were simply assumed not to possess them, or at least not to possess the same kinds of intangible assets as the classic MNEs from the rich countries (Lall, 1983, p. 4). This paradox becomes more evident with the second wave of FDI from the developing world, the one starting in the late 1980s. In contrast with the first wave of FDI from emerging countries that took place in the 1960s and '70s, the new MNEs of the 1980s and '90s aimed at becoming world leaders in their respective indus- 


\section{Table 1}

\section{The New Multinational Enterprises Compared to Traditional Multinationals}

\begin{tabular}{|c|c|c|}
\hline Dimension & New MNEs & Traditional MNEs \\
\hline Speed of internationalization & Accelerated & Gradual \\
\hline Competitive advantages & Weak: Upgrading of resources required & Strong: Required resources available in-house \\
\hline Political capabilities & $\begin{array}{l}\text { Strong: Firms used to unstable political } \\
\text { environments }\end{array}$ & $\begin{array}{l}\text { Weak: Firms used to stable political } \\
\text { environments }\end{array}$ \\
\hline Expansion path & $\begin{array}{l}\text { Dual path: Simultaneous entry into } \\
\text { developed and developing countries }\end{array}$ & $\begin{array}{l}\text { Simple path: From less to more distant } \\
\text { countries }\end{array}$ \\
\hline Default entry modes & $\begin{array}{l}\text { External growth: Alliances and } \\
\text { acquisitions }\end{array}$ & Internal growth: Wholly owned subsidiaries \\
\hline Organizational adaptability & $\begin{array}{l}\text { High, because of their meager } \\
\text { international presence }\end{array}$ & $\begin{array}{l}\text { Low, because of their ingrained structure and } \\
\text { culture }\end{array}$ \\
\hline
\end{tabular}

tries, not just marginal players (Mathews, 2006). In addition, the new MNEs do not come only from emerging countries. Some firms, labeled as born-globals or born-again born-globals (Bell, McNaughton, \& Young, 2001), have emerged from developed countries following accelerated paths of internationalization that challenge the conventional view of international expansion.

The main features of the new MNEs, as compared to the traditional ones, appear in Table 1. The dimensions in the table highlight the key differences between new and conventional MNEs. Perhaps the most startling one has to do with the accelerated pace of internationalization of the new MNEs, as firms from emerging economies have attempted to close the gap between their market reach and the global presence of the MNEs from developed countries (Mathews, 2006).

A second feature of the new MNEs is that all of them, no matter the home country, have been forced to deal not only with the liability of foreignness, but also with the liability and competitive disadvantage that stem from being latecomers lacking the resources and capabilities of established MNEs from the most advanced countries. For this reason, the international expansion of the new MNEs runs in parallel with a capability upgrading process through which newcomers seek to gain access to external resources and capabilities in order to catch up with their more advanced competitors, that is, to reduce their competitiveness gap with established MNEs (Aulakh, 2007; Li, 2007; Mathews, 2006). However, despite lacking the resource endowment of MNEs from devel- oped countries, the new MNEs usually have an advantage over them, as they tend to possess better political capabilities. As the new MNEs are more used to dealing with discretionary and/or unstable governments in their home country, they are better prepared than the traditional MNEs to succeed in foreign countries characterized by a weak institutional environment (Cuervo-Cazurra $\&$ Genc, 2008). Taking into account the high growth rates of emerging countries and their peculiar institutional environments, political capabilities have been especially valuable for the new MNEs.

The first two features taken together point to another key characteristic of the new MNEs: They face a significant dilemma when it comes to international expansion because they need to balance the desire for global reach with the need to upgrade their capabilities. They can readily use their home-grown competitive advantages in other emerging or developing countries, but they must also enter more advanced countries in order to expose themselves to sophisticated, cuttingedge demand and develop their capabilities. This tension is reflected in Figure 1. Firms may evolve in a way that helps them upgrade their capabilities or gain geographic reach, or both. Along the diagonal, the firm pursues a balanced growth path. Above the diagonal it enters the region of capability building, in which the firm sacrifices the number of countries entered (its geographic reach) so as to close the gap with other competitors, especially in the advanced economies. Below the diagonal the firm enters the unsustainable 


\section{Figure 1}

Expansion Paths of New MNEs in Developed and Developing Countries

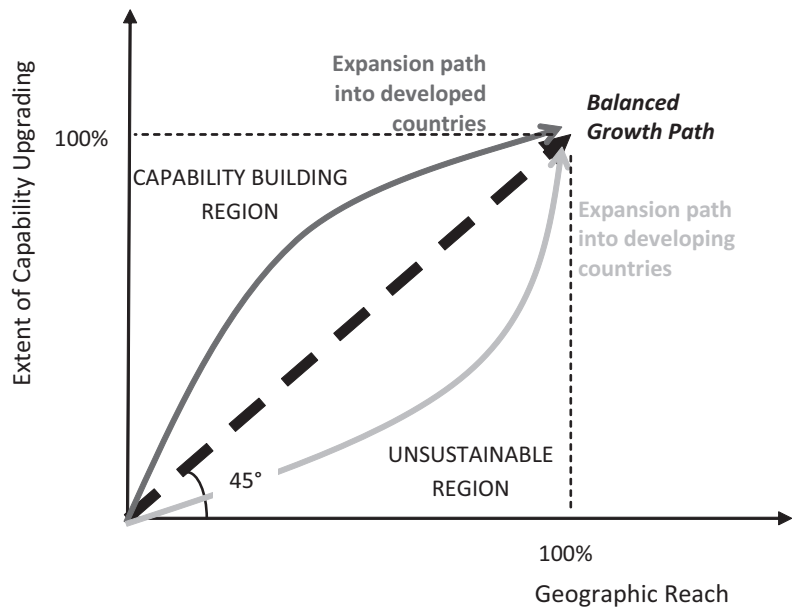

region because prioritizing global reach without improving firm competencies jeopardizes the capability upgrading process. The tension between capability upgrading and gaining global reach forces the new MNEs to enter developed and developing countries simultaneously from the beginning of their international expansion. Entering developing countries helps them gain size and operational experience and generate profits, while venturing into developed ones contributes primarily to the capability upgrading process. The new MNEs have certainly tended to expand into developing countries at the beginning of their international expansion and limit their presence in developed countries to only a few locations where they can build capabilities, either because they have a partner there or because they have acquired a local firm. As they catch up to established MNEs, they begin to invest more in developed countries.

A fourth feature of the new MNEs is their preference for entry modes based on external growth. Global alliances (García-Canal et al., 2002) and acquisitions (Rui \& Yip, 2008) are used by these firms to simultaneously overcome the liability of foreignness in the country of the partner/target and to gain access to their competitive advantages with the aim of upgrading their own resources and capabilities. When entering into global alliances, the new MNEs have used their home market position to facilitate the entry of their partners in exchange for reciprocal access to the partners' home markets and/or technology. Besides the size of the domestic market, the stronger the position of new MNEs in it the greater their bargaining power to enter into these alliances. This fact is illustrated by the case of some new MNEs competing in the domestic appliances industry, such as China's Haier, Mexico's Mabe, and Turkey's Arcelik, whose international expansion was boosted by alliances with world leaders that allowed them to upgrade their technological competencies (Bonaglia et al., 2007). Capability upgrading processes based on acquisitions have been possible in some cases due to the new MNEs' privileged access to financial resources, because of government subsidies or capital market imperfections, as illustrated by the Chinese MNEs (Buckley et al., 2007).

A final feature of the new MNEs is that they enjoy more freedom to implement organizational innovations to adapt to the requirements of globalization because they do not face the constraints typical of established MNEs. As major global players with long histories, many MNEs from the developed economies suffer from inertia and path dependence due to their deeply ingrained values, culture, and organizational structure. Mathews (2006) showed how the new MNEs from Asia have adopted a number of innovative organizational forms that suited their needs, including networked and decentralized structures.

When analyzing the foreign investments of the new MNEs of the 1960s and 1970s, scholars focused their attention on two important questions: their motivations and their proprietary, firm-specific advantages, if any. The following sections deal with these two issues.

\section{Motivations of New MNEs}

Table 2 summarizes the main motivations identified in the literature. As noted above, scholars documented and readily explained the desire of some of the new MNEs to create backward linkages into sources of raw materials or forward linkages into foreign markets in order to reduce uncertainty and opportunism in the relationship between the firm and the supplier of the raw material, or between the firm and the distributor 


\section{Table 2}

Motivations for Foreign Direct Investment by the New Multinational Enterprises

\begin{tabular}{|l|l|l|}
\hline \multicolumn{1}{|c|}{ Motivation } & \multicolumn{1}{c|}{ Description } & \multicolumn{1}{c|}{ References } \\
\hline Backward linkage into raw materials & $\begin{array}{l}\text { Firm seeks to secure supplies of crucial inputs } \\
\text { in the face of uncertainty or asset specificity }\end{array}$ & $\begin{array}{l}\text { Fields, 1995; Lall, 1983; UNCTAD, } \\
\text { 2006; Wells, 1983 }\end{array}$ \\
\hline Forward linkage into foreign markets & $\begin{array}{l}\text { Firm seeks to secure access to the market in } \\
\text { the presence of asset specificity }\end{array}$ & $\begin{array}{l}\text { Fields, 1995; UNCTAD, 2006; } \\
\text { Wells, 1983 }\end{array}$ \\
\hline Home-country government curbs & $\begin{array}{l}\text { Firm attempts to overcome growth } \\
\text { restrictions imposed by the government in its } \\
\text { home market }\end{array}$ & $\begin{array}{l}\text { Lall, 1983; UNCTAD, 2006; Wells, } \\
\text { 1983 }\end{array}$ \\
\hline Spreading of risk & $\begin{array}{l}\text { Firm locates assets in different countries to } \\
\text { manage risk }\end{array}$ & Lecraw, 1977 \\
\hline Movement of personal capital abroad & $\begin{array}{l}\text { Firm invests abroad so that owners diversify } \\
\text { their exposure to any one country }\end{array}$ & Wells, 1983 \\
\hline $\begin{array}{l}\text { Following a home-country customer } \\
\text { to foreign markets }\end{array}$ & $\begin{array}{l}\text { Firm follows home-country customers as they } \\
\text { expand horizontally to other countries }\end{array}$ & UNCTAD, 2006; Wells, 1983 \\
\hline $\begin{array}{l}\text { Investment in new markets in } \\
\text { response to economic reforms in the } \\
\text { home country }\end{array}$ & $\begin{array}{l}\text { Firm enjoying monopolistic or oligopolistic } \\
\text { position in the home market is threatened by } \\
\text { liberalization, deregulation, and/or } \\
\text { privatization policies }\end{array}$ & Goldstein, 2007; Guillén, 2005 \\
\hline $\begin{array}{l}\text { Acquisition of firm-specific intangible } \\
\text { assets }\end{array}$ & $\begin{array}{l}\text { Firm invests or acquires assets in more } \\
\text { developed countries }\end{array}$ & \\
\hline $\begin{array}{l}\text { Exploitation of firm-specific } \\
\text { intangible assets }\end{array}$ & \begin{tabular}{l} 
See Table 3 \\
\hline
\end{tabular} & Lall, 1983; UNCTAD, 2006 \\
\hline
\end{tabular}

or agent in the foreign market. Research documented, especially in the cases of South Korean and Taiwanese firms, their drive to internalize backward and forward linkages through the creation of trading companies, in some cases with government encouragement and financial support (Fields, 1995, pp. 183-237). For example, while during the 1960s a tiny proportion of South Korea's exports reached foreign markets through the distribution and sale channels established by South Korean firms, by the 1980s roughly 50\% of them were fully internalized, that is, handled by the exporters themselves (Cho, 1987). As would be expected, the new MNEs felt the pressures of uncertainty and asset specificity more strongly if they had developed intangible assets. For instance, using evidence from a representative crosssectional sample of 837 Spanish exporting firms as of 1992, Campa and Guillén (1999) found that those with greater expenditures on $R \& D$ were more likely to internalize export operations. A recent survey of the empirical evidence concluded that many of the new MNEs, especially in the extractive and manufacturing sectors, became multinationals when they internalized backward or forward linkages (UNCTAD, 2006).

Scholars also documented that developingcountry MNEs wished to expand abroad in order to overcome limitations imposed by the homecountry government in the domestic market. In many developing and newly industrialized countries, limitations such as licensing systems, quota allocations, and export restrictions kept firms from having enough growth opportunities at their disposal, hence the desire to expand abroad (Lall, 1983; Wells, 1983). In part related to the previous motive, firms felt the need to spread risks by locating assets in different countries (Lecraw, 1977). This motivation was driven by the macroeconomic and political volatility characteristic of so many developing and newly industrialized countries. A variation on this effect has to do with the case of family-owned MNEs from developing countries under the threat of government scrutiny or confiscation (Wells, 1983).

The early literature on the new MNEs also identified buyer-supplier relationships as motives for a supplier establishing production facilities in a 
foreign country in which the buyer already had a presence (UNCTAD, 2006; Wells 1983). In some cases, both the buyer and the supplier are homecountry firms that followed each other abroad, while in others the buyer is a multinational from a developed country that asks its supplier in a developing or newly industrialized country to colocate either in its home country or in other countries (Guillén, 2005).

\section{Firm-Specific Assets}

Scholars also devoted attention to the proprietary, firm-specific intangible assets of the new MNEs, noting that they engaged in foreign direct investment with the purpose of not only acquiring such assets but also exploiting existing ones. Foreign expansion with a view to acquiring intangible assets, especially technology and brands, was not very important during the 1970s and 1980s, but has become widespread in the last two decades (UNCTAD, 2006). With the advent of current account and currency exchange liberalization in many developing and newly industrialized countries, the new MNEs have enjoyed more of a free hand in terms of making acquisitions, including multibillion-dollar deals. Many of these have targeted troubled companies or divisions located in the United States and Europe that possess some brands and product technology that the new MNE is in a better position to exploit because of its superior or more efficient manufacturing abilities.

Acquisitions have not been the only way to gain access to intangible assets. The evidence suggests that the acceleration in the international expansion of the new MNEs has been backed by a number of international alliances aimed at gaining access to critical resources and skills that allow these firms to catch up to MNEs from developed countries. As argued above, these alliances and acquisitions have been critical for these firms to match the competitiveness of MNEs from developed countries. For this reason the international expansion of new MNEs runs in parallel with the process of upgrading their capabilities. Sometimes, however, capability upgrading precedes international expansion. This is the case, for instance, for some state-owned enterprises that undergo a restructuring process before their internationaliza- tion and privatization (Cuervo \& Villalonga, 2000).

In other cases the capability upgrading process can follow international expansion. This can happen in regulated industries, where firms face strong incentives to commit large amounts of resources and to establish operations quickly, whenever and wherever opportunities arise, and frequently via acquisition as opposed to greenfield investment (García-Canal \& Guillén, 2008; Sarkar et al., 1999). As opportunities for international expansion in these industries depend on privatization and deregulation, some firms lacking competitive advantages expand abroad on the basis of free cash flows as opportunities arise.

As noted above, horizontal investments seemed to pose a challenge to established theories of the MNE. The literature had emphasized since the late 1950s that MNEs in general undertake horizontal investments on the basis of intangible assets such as proprietary technology, brands, or knowhow. The early literature on the new multinationals simply assumed that firms from developing or newly industrialized countries lacked the kind of intangible assets characteristic of American, Japanese, and European multinationals (Lall, 1983, p. 4). In fact, study after study found that the new multinationals scored lower on technology, marketing skill, organizational overhead, scale, capital intensity, and control over foreign subsidiaries than their rich-country counterparts (e.g. Lall, 1983; Lecraw, 1977; Wells, 1983).

Still, horizontal investments cannot be explained without the presence of intangible assets of some sort. Table 3 summarizes the main types of intangible assets possessed by the new MNEs, as reflected in the existing literature. During the 1970s and 1980s, the scholarly attention focused on capabilities such as the adaptation of technology to the typically smaller scale markets of developing and newly industrialized countries, their cheaper labor, or imperfect input markets (Ferrantino, 1992; Heenan \& Keegan, 1979, Lall, 1983; Lecraw, 1977; Tolentino, 1993). Consumergood MNEs from these countries were also found to possess a different kind of intangible asset, namely, "ethnic brands" that appealed to customers not only in the home market but also to the 


\section{Table 3}

\section{Infangible Assets of the New Multinational Enterprises}

\begin{tabular}{|c|c|c|}
\hline Intangible Asset & Description & References \\
\hline Technology adaptation & $\begin{array}{l}\text { Adaptation of available technology to small-scale } \\
\text { product markets, cheap labor, and/or imperfect } \\
\text { input markets }\end{array}$ & $\begin{array}{l}\text { Ferrantino, 1992; Heenan \& Keegan, } \\
\text { 1979; Lall, 1983; Lecraw, 1977; } \\
\text { Tolentino, } 1993\end{array}$ \\
\hline Early adoption of new technology & $\begin{array}{l}\text { Implementation of new technology developed by } \\
\text { someone else, especially in infrastructure } \\
\text { industries such as construction, electricity, or } \\
\text { telecommunications }\end{array}$ & Guillén, 2005; UNCTAD, 2006 \\
\hline Ethnic branding & $\begin{array}{l}\text { Consumer brands with appeal to immigrant } \\
\text { home-country communities abroad }\end{array}$ & $\begin{array}{l}\text { Ferrantino, 1992; Heenan \& Keegan, } \\
\text { 1979; Lall, 1983; Lecraw, 1977; } \\
\text { Wells, } 1983\end{array}$ \\
\hline $\begin{array}{l}\text { Efficient production and project } \\
\text { execution }\end{array}$ & $\begin{array}{l}\text { Ability to absorb technology, combine resources, } \\
\text { and innovate from an organizational point of } \\
\text { view in ways that reduce costs and enhance } \\
\text { learning }\end{array}$ & $\begin{array}{l}\text { Amsden \& Hikino, 1994; Goldstein, } \\
\text { 2007; Guillén, 2000; Kock \& Guillén, } \\
\text { 2001; Mathews, 2006; UNCTAD, } \\
2006\end{array}$ \\
\hline Product innovation & $\begin{array}{l}\text { Incremental product improvements; specialized } \\
\text { products for market niches }\end{array}$ & Lall, 1983; UNCTAD, 2006 \\
\hline Institutional entrepreneurial ability & $\begin{array}{l}\text { Skills or know-how needed to operate in the } \\
\text { peculiar institutional conditions of less developed } \\
\text { countries }\end{array}$ & $\begin{array}{l}\text { Caves, 1996; Lall, 1983; Lecraw, } \\
1993\end{array}$ \\
\hline $\begin{array}{l}\text { Expertise in the management of } \\
\text { acquisitions }\end{array}$ & $\begin{array}{l}\text { Experience gained in the home country in the } \\
\text { management of M\&As and corporate } \\
\text { restructuring that help to extract value from } \\
\text { cross-border acquisitions }\end{array}$ & Guillén, 2005 \\
\hline Networking skills & $\begin{array}{l}\text { Ability to develop networks of cooperative } \\
\text { relationships }\end{array}$ & $\begin{array}{l}\text { Buckley et al., 2007; Dunning, 2002; } \\
\text { Mathews, } 2006\end{array}$ \\
\hline Political know-how & $\begin{array}{l}\text { Advantage in dealing with host governments and } \\
\text { with political risk in less developed countries }\end{array}$ & $\begin{array}{l}\text { García-Canal \& Guillén, 2008; Lall, } \\
\text { 1983; Lecraw, } 1977\end{array}$ \\
\hline
\end{tabular}

ethnic diaspora in foreign countries, especially in Europe and the United States (Ferrantino, 1992; Goldstein, 2007, pp. 117-122; Lecraw, 1977; Wells, 1983). Other scholars noted that the new MNEs possessed an uncanny ability to incrementally improve available products and to develop specialized variations for certain market niches (Lall, 1983; UNCTAD, 2006).

During the 1980s, students of the so-called East Asian miracle highlighted yet another intangible asset, one having to do with the ability to organize production and to execute large-scale projects efficiently with the help of technology borrowed from abroad in industries as diverse as steel, electronics, automobiles, shipbuilding, infrastructure development, and turnkey plant construction (Amsden \& Hikino, 1994). Scholars also proposed that these capabilities facilitated the growth of diversified business groups (Guillén, 2000;
Kock \& Guillén, 2001), which in turn made it easier for firms within the same group to expand and invest abroad by drawing on shared financial, managerial, and organizational resources (Goldstein, 2007, pp. 87-93; Guillén, 2002; Lall, 1983, p. 6; Mathews, 2006; UNCTAD, 2006). A specific type of managerial skill that becomes critical in accelerated internationalization is the ability to effectively manage mergers and acquisitions or strategic alliances. These abilities become critical when extracting value from such organizational combinations, which are necessary to learn and gain access to critical external knowledge and resources (Kale et al., 2000; Zollo \& Singh, 2004). Guillén (2005) has shown that the accrued skills in the management of M\&A and corporate restructuring by large Spanish firms competing in regulated industries have been critical for their international expansion in Latin America. Buck- 
ley et al. (2007), analyzing the success of Chinese firms capitalizing on the Chinese diaspora, argued that some firms have the ability to engage in beneficial relationships with other firms that have valuable resources needed to succeed in global markets. The adoption of network-based structures has also helped the development of the new MNEs by making easier the coordination of the international activities (Mathews, 2006). However, home-country networks in several cases have also allowed these firms to take advantage of the experience of the firms from the network (Elango \& Pattnaik, 2007; Yiu et al., 2007).

In more recent years, students of the new MNEs have drawn attention to other types of intangible assets. On the technology side, research has documented that firms in developing, newly industrialized and upper-middle-income countries face lower hurdles when it comes to adopting new technology than do their more established counterparts in rich countries. This is especially the case in industries such as construction, electricity, port operations, and telecommunications, in which companies from Brazil, Chile, Mexico, South Korea, Spain, and Dubai, among other countries, have demonstrated a superior ability to borrow technology and organize efficient operations across many markets (Guillén, 2006; UNCTAD, 2006).

Another area of recent theoretical and empirical research has to do with the political knowhow that the new MNEs seem to possess by virtue of having been forced to operate in heavily regulated environments at first, and then rapidly deregulating ones, as illustrated by the expansion of Spanish banking, electricity, water, and telecommunications firms throughout Latin America and, more recently, Europe (García-Canal \& Guillén, 2008). This "political" capability was not lost on the early students of the new MNEs; they duly pointed out that these firms possessed an "institutional entrepreneurial ability" that enabled them to operate effectively in the peculiar political, regulatory, and cultural conditions characteristic of developing countries (Caves, 1996; Goldstein, 2007, pp. 99-102; Lall, 1983; Lecraw, 1993). Political and regulatory risk management was identified in some early studies as a key competitive capability (Lall, 1983; Lecraw, 1977). In the last 20 years, a new twist has been added to this theoretical insight after the observation that the new MNEs are making acquisitions and increasing their presence in the infrastructure industries of the rich countries of Europe and North America, including electricity generation and distribution; telecommunications; water; and airport, port, and toll-highway operation, among others (Guillén, 2005). The recent corporate expansion into Latin America of Spanish firms from regulated industries illustrates how firms tend to invest in those countries where their political capabilities are more valuable, that is, those with high political instability, as shown by García-Canal and Guillén (2008). An interesting result of this study is that Spanish firms from regulated industries reduced over time their propensity to invest in politically unstable countries, showing that it is easier to move from politically unstable countries to stable ones than the other way around.

\section{Patterns of Expansion}

An important point that early students of the new MNEs underplayed was that, depending on the home country, these foreign-investing firms tended to emerge from certain industries and not others (UNCTAD, 2006). Thus, the South Korean MNEs have excelled in automobiles and electronics, the Taiwanese in component manufacturing, the Brazilian in automotive and aerospace products, the Mexican in ethnic brands and in producer goods such as cement, the Spanish in regulated and infrastructure industries, the Indian in information services, the Chinese (so far) in simple assembled goods, and so on. In so doing, firms originating from developing, newly industrialized, and upper-middle-income countries have accumulated proprietary intangible assets that have enabled them to successfully compete through internalized exports and horizontal investments even in the most advanced countries in the world.

This process of "reverse" foreign direct investment from home countries at a lower level of development than the host countries to which it is directed is anomalous only in a superficial way. The overall level of development of a country, as 
measured by such aggregate indicators as GDP per capita, more likely than not conceals a heterogeneous mix of backward and world-class industries and firms. Many countries around the world include pockets or enclaves of excellence surrounded by relatively mediocre or even inefficient producers. The literature on geographical clusters and agglomeration economies has shown that firms build capabilities as they interact with others located in close proximity (Cortright, 2006; Porter, 1998). This literature emphasizes that the country level of analysis is not the appropriate one for understanding the impact of location and geography. Ironically, one of the facilitating factors in the development of these clusters and enclaves of excellence could be incoming FDI and outsourcing agreements from firms located in developed countries that contributed to the formation of industrial clusters in less developed ones (McKendrick et al., 2001; Meyer, 2004).

The new MNEs have tended to follow some of the patterns of expansion consistent with product life cycle and staged theories of internationalization, as they have tended to expand first into countries located within the same region (Goldstein, 2007; Lall, 1983; Wells, 1983). In addition, when stepping outside their home region, they have tended to emphasize areas culturally, politically, or economically similar, as in the case of the Spanish firms' expansion into Latin America (Guillén, 2005). However, notable exceptions to this pattern have to do with investments in search of strategic assets (Goldstein, 2007, pp. 85-87) and the rapid pace at which they have expanded their global reach (Mathews, 2006).

\section{Conclusion}

$\mathrm{T}$ he new MNEs are the result of both imitation of established MNEs from the rich countrieswhich they have tried to emulate both strategically and organizationally-and innovation in response to the peculiar characteristics of emerging and developing countries. The context in which their international expansion has taken place is also relevant. The new MNEs have emerged from countries with weak institutional environments, property rights regimes, legal systems, and so on. Experience in the home country was especially valuable for the new MNEs because many countries with weak institutions are growing fast, and these MNEs developed the capabilities to compete in such challenging environments.

In addition, the new MNEs have flourished at a time of market globalization in which, despite local differences that still remain, global reach and global scale are crucial. The new MNEs have responded to this challenge by embarking on an accelerated international strategy based on external growth aimed at upgrading their capabilities and increasing their global market reach. When implementing this strategy, the new MNEs took advantage of their market position in the home country, and, ironically, their meager international presence allowed them to adopt a strategy and organizational structure that happens to be most appropriate to the current international environment in which emerging economies are growing very fast.

It is also important to note that the established MNEs from the rich countries have adopted some of the behaviors of the new multinationals. Increased competitive pressure from the latter in industries such as cement, steel, electrical appliances, construction, banking, and infrastructure has prompted many American and European firms to become much less reliant on traditional product-differentiation strategies and vertically integrated structures. To a certain extent, the rise of networked organizations (e.g., Bartlett \& Ghoshal, 1989) and the extensive shift toward outsourcing represent competitive responses to the challenges faced by established MNEs. Finally, a special type of new MNE is the so-called born-global firm, which resembles the new MNE in many ways but has emerged from developed countries.

Taking all these developments into account, it is clear that the American model of MNE is fading. In effect, globalization, technical change, and the coming of age of the emerging countries have facilitated the rise of a new type of MNE in which foreign direct investment is driven not only by the exploitation of firm-specific competencies but also by the exploration of new patterns of innovation and ways of accessing markets. In addition, the new MNEs have expanded 
rapidly, without following the gradual staged model of internationalization.

It is important to note, however, that the decline of the American model of the MNE does not necessarily imply the demise of existing theories of the MNE. In fact, the core explanation for the existence of MNEs remains: In order to pursue international expansion the firm needs to possess capabilities allowing it to overcome the liability of foreignness; no firm-specific capabilities, no multinationals. Our analysis of the new MNEs has shown that their international expansion was possible due to some valuable capabilities developed in the home country, including project-execution and political and networking skills, among other nonconventional ones. Thus, the lack of the classic technological or marketing capabilities does not imply the absence of other valuable capabilities that may provide the foundations for international expansion. It is precisely for this reason that the new MNEs are here to stay.

\section{References}

Accenture. (2008). The rise of the emerging-market multinational. Retrieved April 8, 2009, from http:/www.accenture.com/NR/ rdonlyres/2835C9BA-2077-4C68-B1CD-8B87DC9F009B/0/ MPW2Jan08.pdf.

Amsden, A. H., \& Hikino, T. (1994). Project execution capability, organizational know-how and conglomerate corporate growth in late industrialization. Industrial and Corporate Change, 3(1), 111-147.

Aulakh, P. S. (2007). Emerging multinationals from developing economies: Motivations, paths and performance. Journal of International Management, 13(3), 235-240.

Bartlett, C. A., \& Ghoshal, S. (1989). Managing across borders: The transnational solution. Boston: Harvard Business School Press.

BCG. (2008). The 2008 BCG 100 new global challengers: How top companies from rapidly developing economies are changing the world. Retrieved April 8, 2009, from http://www.bcg. com/impact_expertise/publications/publication_list.jsp? pubID $=2495$.

Bell, J., McNaughton, R., \& Young, S. (2001). Born-again global firms: An extension to the born global phenomenon. Journal of International Management, 7(3), 173190.

Bonaglia, F., Goldstein, A., \& Mathews, J. A. (2007). Accelerated internationalization by emerging markets multinationals: The case of the white goods sector. Journal of World Business, 42, 369-383.

Buckley, P. J., Clegg, L. J., Cross, A. R., Liu, X., Voss, H., \& Zheng, P. (2007). The determinants of Chinese outward foreign direct investment. Journal of International Business Studies, 38, 499-518.
Campa, J. M., \& Guillén, M. F. (1999). The internalization of exports: Firm and location-specific factors in a middleincome country. Management Science, 45(11), 14631478.

Caves, R. E. (1996). Multinational enterprise and economic analysis. New York: Cambridge University Press.

Chandler, A. D. (1990). Scale and scope: The dynamics of industrial capitalism. Cambridge, MA: Harvard University Press.

Cho, D.-S. (1987). The general trading company: Concept and strategy. Lexington, MA: Lexington Books.

Cortright, J. (2006). Making sense of clusters: Regional competitiveness and economic development. (Discussion Paper). Washington, DC: The Brookings Institution Metropolitan Policy Program.

Cuervo, A., \& Villalonga, B. (2000). Explaining the variance in the performance effects of privatization. Academy of Management Review, 25, 581-590.

Cuervo-Cazurra, A., \& Genc, M. (2008). Transforming disadvantages into advantages: Developing-country MNEs in the least developed countries. Journal of International Business Studies, 39, 957-979.

Economist. (2008, January 10). The challengers. The Economist.

Elango, B., \& Pattnaik, C. (2007). Building capabilities for international operations through networks: A study of Indian firms. Journal of International Business Studies, 38, 541-555.

Ferrantino, M. J. (1992). Technology expenditures, factor intensity, and efficiency in Indian manufacturing. Review of Economics and Statistics, 74(4), 689-700.

Fields, K. J. (1995). Enterprise and the State in Korea and Taiwan. Ithaca, NY: Cornell University Press.

García-Canal, E., \& Guillén, M. F. (2008). Risk and the strategy of foreign location choice in regulated industries. Strategic Management Journal, 29, 1097-1115.

García-Canal, E., López Duarte, C., Rialp Criado, J., \& Valdés Llaneza, A. (2002). Accelerating international expansion through global alliances: A typology of cooperative strategies. Journal of World Business, 37(2), 91107.

Goldstein, A. (2007). Multinational companies from emerging economies. New York: Palgrave Macmillan.

Guillén, M. F. (2000). Business groups in emerging economies: A resource-based view. Academy of Management Journal, 43(3), 362-380.

Guillén, M. F. (2002). Structural inertia, imitation, and foreign expansion: South Korean firms and business groups in China, 1987-1995. Academy of Management Journal, 45(3), 509-525.

Guillén, M. F. (2005). The rise of Spanish multinationals: European business in the global economy. Cambridge, England: Cambridge University Press.

Heenan, D. A., \& Keegan, W. J. (1979). The rise of third world multinationals. Harvard Business Review, 57(January-February), 101-109.

Henisz, W. J. (2003). The power of the Buckley and Casson thesis: The ability to manage institutional idiosyncrasies. Journal of International Business Studies, 34, 173-184.

Hoffmann, W. H. (2007). Strategies for managing a portfo- 
lio of alliances. Strategic Management Journal, 28(8), 827-856.

Hymer, S. (1960/1976). The international operations of national firms: A study of direct foreign investment. Cambridge, MA: The MIT Press.

Johanson, J., \& Vahlne, J. E. (1977). The internationalization process of the firms: A model of knowledge development and increasing foreign market commitments. Journal of International Business Studies, 8(1), 23-32.

Johanson, J., \& Wiedersheim-Paul, F. (1975). The internationalization of the firm: Four Swedish cases. Journal of Management Studies, October, 305-322.

Kale, P., Singh, H., \& Perlmutter, H. V. (2000). Learning and protection of proprietary assets in strategic alliances: Building relational capital. Strategic Management Journal, 21, 217-237.

Kindleberger, C. P. (1969). American business abroad. New Haven, CT: Yale University Press.

Kock, C., \& Guillén, M. F. (2001). Strategy and structure in developing countries: Business groups as an evolutionary response to opportunities for unrelated diversification. Industrial $\&$ Corporate Change, 10(1), 1-37.

Lall, S. (1983). The new multinationals. New York: Wiley.

Lecraw, D. (1977). Direct investment by firms from less developed countries. Oxford Economic Papers, 29(November), 445-457.

Li, P. P. (2003). Toward a geocentric theory of multinational evolution: The implications from the Asian MNEs as latecomers. Asia Pacific Journal of Management, 22(2), 217-242.

Li, P. P. (2007). Toward an integrated theory of multinational evolution: The evidence of Chinese multinational enterprises as latecomers. Journal of International Management, 13(3), 296-318.

Mathews, J. A. (2002). Dragon multinationals: A new model of global growth. New York: Oxford University Press.

Mathews, J. A. (2006). Dragon multinationals. Asia Pacific Journal of Management, 23, 5-27.

McKendrick, D.G., Doner, R.F., \& Haggard, S. (2001). From Silicon Valley to Singapore: Location and competitive advantage in the hard disk drive industry. Palo Alto, CA: Stanford University Press.
Meyer, K. E. (2004). Perspectives on multinational enterprises in emerging economies. Journal of International Business Studies, 35, 259-276.

Porter, M. E. (1988). Clusters and the new economics of competition. Harvard Business Review, 76(6), 77-90.

Rui, H., \& Yip, G. S. (2008). Foreign acquisitions by Chinese firms: A strategic intent perspective. Journal of World Business, 43, 213-226.

Sarkar, M. B., Cavusgil, S. T., \& Aulakh, P. S. (1999). International expansion of telecommunications carriers: The influence of market structure, network characteristics and entry imperfections. Journal of International Business Studies, 30, 361-382.

Stopford, J. M., \& Wells, L. T. (1972). Managing the multinational enterprise. New York: Basic Books.

Tolentino, P. E. E. (1993). Technological innovation and third world multinationals. London: Routledge.

UNCTAD (United Nations Conference on Trade and Development). (2006). World Investment Report 2006. New York: United Nations.

Vernon, R. (1966). International investment and international trade in the product cycle. Quarterly Journal of Economics, 80, 190-207.

Vernon, R. (1979). The product cycle hypothesis in a new international environment. Oxford Bulletin of Economics and Statistics, 41(4), 255-267.

Wells, L. T. (1983). Third world multinationals: The rise of foreign investment from developing countries. Cambridge, MA: The MIT Press.

Wilkins, M. (1974). The maturing of multinational enterprise: American business abroad from 1914 to 1970. Cambridge, MA: Harvard University Press.

Yiu, D. W., Lau, C. M., \& Bruton, G. D. (2007). International venturing by emerging economy firms: The effects of firm capabilities, home country networks, and corporate entrepreneurship. Journal of International Business Studies, 38, 519-540.

Zollo, M., \& Singh, H. (2004). Deliberate learning in corporate acquisitions: Post-acquisition strategies and integration capability in U.S. bank mergers. Strategic Management Journal, 25, 1233-1256. 